\title{
THRESHOLDS OF METAL AND METALLOID TOXICITY IN FIELD-COLLECTED ANTHROPOGENICALLY CONTAMINATED SOILS: A REVIEW
}

\author{
Javier Santa-Cruz' ${ }^{1}$ Patricia Peñaloza ${ }^{2}$, Maria V. Korneykova ${ }^{3}$, Alexander Neaman ${ }^{4 *}$ \\ 'Escuela de Ciencias Agrícolas y Veterinarias, Universidad Viña del Mar, Viña del Mar, Chile \\ Escuela de Agronomía, Pontificia Universidad Católica de Valparaíso, Quillota, Chile \\ ${ }^{3}$ Department of Landscape Design and Sustainable Ecosystems, Peoples Friendship University of Russia (RUDN \\ University), Moscow, Russia \\ ${ }^{4}$ Instituto de Ingeniería Agraria y Suelos, Facultad de Ciencias Agrarias y Alimentarias, Universidad Austral de Chile, \\ Valdivia, Chile
}

*Corresponding author: alexander.neaman@gmail.com

Received: March 3 ${ }^{\text {th }}, 2021 /$ Accepted: May 25 th, 2021 / Published: July $1^{\text {st }}, 2021$

https://DOI-10.24057/2071-9388-2021-023

\begin{abstract}
Ecotoxicological studies of soil metal toxicity conventionally rely on the use of uncontaminated soils gradually enriched with metals in the form of soluble salts. Although this method is very useful in many ways, it is continually complicated by the difficulty of extrapolating laboratory results to actual field-collected soils exposed to decades of contamination. Although many studies emphasize the importance of using field-contaminated soils for toxicity bioassays, the number of studies actually conducted based on this premise is relatively small. This review provides an in-depth recompilation of data on metal toxicity thresholds in field-contaminated soils. We have summarized the $\mathrm{EC}_{10^{\prime}} \mathrm{EC}_{25^{\prime}}$ and $\mathrm{EC}_{50}$ values for metals, i.e., values of metal concentrations that reduce the response of specific organisms by $10 \%, 25 \%$, and $50 \%$ of the value in uncontaminated soils. In our summary, most studies show that total metal content can predict organismal responses as well as bioavailable fractions. These results are consistent with the intensity/capacity/quantity concept proposed for plant nutrient uptake. In addition, microorganisms are thought to be more sensitive to metals than plants and invertebrates. However, our analysis shows that there is no statistically significant difference between the sensitivity of microorganisms and other organisms (plants and invertebrates) to any metal or metal pool. We expect that this information will be useful for environmental assessment and soil quality decisions. Finally, we encourage future studies to analyze dose-effect relationships in native field-collected soils with varying degrees of metal contamination from long-term anthropogenic pollution.
\end{abstract}

KEYWORDS: artificially polluted soil; metal-enriched soil, metal-spiked soil; field-collected soil; field-contaminated soil; ecotoxicity thresholds

CITATION: Javier Santa-Cruz, Patricia Peñaloza, Maria V. Korneykova, Alexander Neaman (2021). Thresholds of Metal and Metalloid Toxicity In Field-Collected Anthropogenically Contaminated Soils: A Review. Geography, Environment, Sustainability, Vol. 14, No 2, p. 6-21 https://DOI-10.24057/2071-9388-2021-023

ACKNOWLEDGMENTS: The study was funded by the Russian Foundation for Basic Research (RFBR), project number 20-1450002. The authors also wish to thank Evgenii L. Vorobeichik for helpful comments and Andrei Tchourakov for editing this article.

Conflict of interests: The authors reported no potential conflict of interest.

\section{SCOPE OF THE REVIEW}

Ecotoxicology analyzes the effects of chemicals on organisms in the environment. Its ultimate goal is to protect the structure and functioning of ecosystems. It is achieved by assessing any exposure to a single species of certain test organisms and then extrapolating the resulting effective concentrations to safe levels for populations and communities (van Gestel 2012). In turn, soil ecotoxicology is an interdisciplinary field of science that studies the toxicological effects of chemicals on soil ecology (Hooper and Anderson 2008) to reduce the risks that certain human activities pose to soil ecosystems. In particular, soil contamination by metals and metalloids has become a serious threat to the environment in the era of industrialization (e.g., Korkina and Vorobeichik 2018). In the discussion that follows, the term "metal" includes metalloids (such as arsenic) for the sake of simplicity.

This review provides an in-depth recompilation of data on metal toxicity thresholds in soils exposed to decades of contamination. In the discussion that follows, the latter type of soils is referred to as "fieldcollected" or "field-contaminated" soils. We conducted an exhaustive review of the literature reporting dose-effect relationships in field-collected soils and omitted all studies that used metal-spiked soils, i.e., uncontaminated soils gradually spiked in a laboratory 
setting with metals in the form of soluble salts. We summarized the $\mathrm{EC}_{10}, \mathrm{EC}_{25}$, and $\mathrm{EC}_{50}$ values for metals, i.e., values of metal concentrations that reduce the response of specific organisms by $10 \%, 25 \%$, and $50 \%$ of the value in uncontaminated soils. In our review, we analyzed studies that clearly stated the effective values of metal concentrations in soil. We also reviewed studies in which EC values for metals in soil could be estimated using either reported regressions or the dose-effect relationships shown in the figures.

Most of the responses summarized in this review relate to the individual level of biological organization, as there were not enough responses reported at lower organizational levels (i.e., molecular and cellular) and higher organizational levels (i.e., population, community, and ecosystem). Similarly, this review did not include studies in which it was not possible to determine the effects of any particular metal on organismal responses. In other words, we excluded studies that reported pollution index thresholds rather than thresholds for a particular metal.

\section{SPIKED VERSUS FIELD-CONTAMINATED SOILS}

Ecotoxicological studies of soil metal toxicity conventionally rely on the use of spiked soils. Although this method is very useful in many ways, it is continually complicated by the difficulty of extrapolating laboratory results to actual field soils exposed to decades of contamination (e.g., Neaman et al. 2020). Our comprehensive review of scientific literature conducted earlier (Santa-Cruz et al. 2021) revealed that all studies without exception had greater metal toxicity in spiked soils than in field-contaminated soils. Importantly, this observation held equally true for different types of organisms (e.g., plants, invertebrates, and microorganisms). To give but one example, the average effective concentration 50\% (EC ${ }_{50}$ ) of total copper in spiked soils (354 $\pm 39 \mathrm{mg} \mathrm{kg}^{-1}$ ) was statistically lower than in field-collected soils (987 $\left.\pm 491 \mathrm{mg} \mathrm{kg}^{-1}, \mathrm{p}<0.05\right)$ when plant responses were used as bioindicators of toxicity.

It is a well-known fact that when metals are first introduced into the soil in the form of soluble salts, they exhibit high solubility and toxicity, which gradually decrease. In the scientific literature, this effect is called "aging" (also spelled "ageing"). Even though the concept of metal aging dates back to the 1990s (e.g., Ford et al. 1997), there is still little understanding of the physical, chemical, and biological processes that govern the transformation of metal ions into less soluble or socalled "fixed" forms (McBride and Cai 2016).

In order to overcome the difficulties presented by divergent metal toxicity in spiked versus fieldcollected soils, some researchers employed artificial aging of metal-spiked soils under both laboratory and field conditions. But the necessary duration of aging of metal-spiked soils until ecotoxicity bioassays may be considered realistic remained unclear. The study of McBride and Cai (2016) demonstrated that soils amended with $200-400 \mathrm{mg} \mathrm{kg}^{-1}$ of soluble Cu or Zn salts retained a significant degree of phytotoxicity even after 10 years of field aging. Likewise, the study of Martinez and Martinez-Villegas (2008) revealed that copper solubility decreased in copper-alumina-organic matter mixed systems aged for over 8 years. Therefore, it is safe to say that metal aging is a very slow process that does not yield easily to artificial replication.

\section{TOTAL VERSUS “BIOAVAILABLE” METAL POOLS}

It is believed that total metal concentrations in polluted soil are not sufficient to predict its potential toxicity. Several studies have attempted to forecast the so-called "bioavailable" metal fraction in soil by correlating organism responses with different metal pools in soil (e.g., Lillo-Robles et al. 2020). Assessment of "bioavailable" metal fractions in soil is often done using distilled water or chemically non-aggressive neutral salts. Other methods utilize pore water extracted by the Rhizon soil moisture samplers or the technique of diffusive gradients in thin films (DGT). In the discussion that follows, we will refer to these bioavailable fractions as "extractable" when the researchers chose to express them in mg kg-1 of soil, or "soluble" when the researchers expressed them in $\mathrm{mg} \mathrm{L}^{-1}$ of soil solution (or extraction solution). Soil solution-free metal activities may also be used for assessing metal availability to organisms. In the following discussion, $\mathrm{pMe}^{2+}$ refers to the negative logarithm of $\mathrm{Me}^{2+}$ ion activity, where $\mathrm{Me}^{2+}$ represents $\mathrm{Cu}^{2+}$ or $\mathrm{Zn}^{2+}$ or $\mathrm{Pb}^{2+}$ ion. In is important to emphasize that the lower value of $\mathrm{pMe}^{2+}$ signifies the higher activity of the free $\mathrm{Me}^{2+}$ ion.

Appendices A-E contain the summary of studies that reported correlations between organism responses and various metal pools in soil. However, the data are inconsistent, making interpretations difficult. Yet most of the studies demonstrate that total metal content can predict organism responses just as well as bioavailable fractions (either extractable, soluble, or $\mathrm{pMe}^{2+}$ ). These findings are consistent with the intensity/capacity/ quantity concept proposed for nutrient uptake by plants (Marschner 1993), as discussed in more detail below.

The quantity factor refers to the total element content in the soil. The intensity factor is the concentration of elements in the soil solution, taking into account that this fraction is immediately delivered to the roots at any given time. In turn, the capacity factor is the kinetics of element release, i.e., the buffering capacity of the soil to supply element ions from the solid phase into the soil solution. These are the factors that are known to govern the phytoavailability of nutrients in soils (Fig. 1).

In other words, the absorption of elements by plants depends not only on their concentrations in the soil solution (intensity), but also on the total content of the elements in soil (quantity), and their supply kinetics (capacity). The same is true for metal phytoavailability in soil, which is similarly driven by the intensity/ capacity/quantity factors (e.g., Prudnikova et al. 2020). Likewise, in the study of Sauvé et al. (1996), plant tissues accumulated an average of 2,000 times the amount of total copper dissolved in the solution. This is only possible if copper in the soil solution is buffered by desorption-dissolution mechanisms (Sauvé 2002). For this reason, it is safe to assume that the same factors also control metal availability to soil organisms (such as invertebrates)

In summary, metal toxicity in soil depends on the diverse soil metal pools available to supply metal ions to the soil solution at the time when plant roots or soil organisms uptake metal ions. For this reason, total metal content can predict organism responses just as well as the so-called "bioavailable" fractions. 


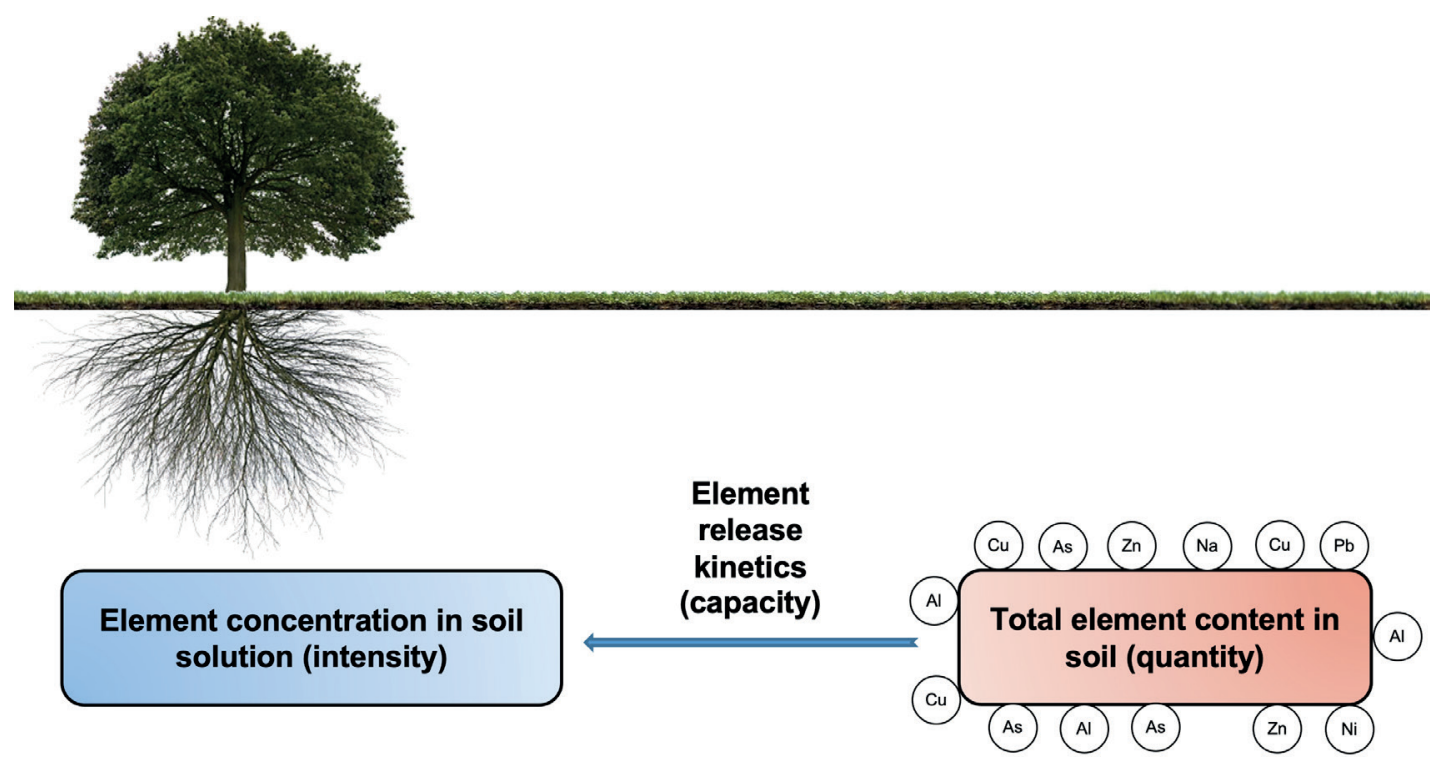

Fig. 1. Intensity, quantity, and capacity factors of element phytoavailability in soils (adapted from Neaman et al. 2021)

\section{METAL TOXICITY THRESHOLDS}

A single effective concentration value for a specific organism response is clearly insufficient to undertake any noteworthy agricultural or ecological endeavor. For this reason, Checkai et al. (2014) proposed to average the effective concentration values for different species and responses. However, this approach ignores the concept of the hierarchical cascade of biological responses to any given stress. According to this concept, the severity of chemical exposure to metals correlates with the complexity of specific levels of biological organization (e.g., Spurgeon et al. 2005). Lower organizational levels (i.e., molecular, cellular, and individual) are more sensitive to different types of stress than higher organizational levels (i.e., population, community, and ecosystem). Table 1 summarizes the studies reporting $\mathrm{EC}_{50}$ values for metals of at least two levels of biological organization, revealing the following order: molecular < cellular < individual.

Thus, an argument can be made that effective concentration values should not be averaged out for responses registered at different levels of biological organization. As mentioned above, most of the responses summarized in this review pertain to the individual level, whereas the number of responses registered at other levels was not sufficient to analyze them separately (Online Supplementary Material). For this reason, Table 2 sums up the responses of different species from all the levels, grouped by three types of organisms: plants, invertebrates, and microorganisms.

It is worth noting that the biggest challenge in using field-collected soils for ecotoxicity assessment has to do with the presence of several metals in the polluted soil. Regression analysis is one of the conventional methods employed to discern the impacts of various metals in fieldcontaminated soils. For instance, in the study of Bustos

Table 1. Plant and earthworm hierarchical biological responses to copper and zinc

\begin{tabular}{|c|c|c|c|c|c|c|}
\hline \multirow{2}{*}{ Metal } & \multirow{2}{*}{ Study } & \multirow{2}{*}{ Species } & \multirow{2}{*}{ LBO } & \multirow{2}{*}{ EP } & Total (mg kg-1) & $\mathrm{pMe}^{2+}$ \\
\hline & & & & & $\mathrm{EC}_{50}$ & $\mathrm{EC}_{50}$ \\
\hline \multirow{7}{*}{$\mathrm{Cu}$} & \multirow{5}{*}{ Kolbas et al. (2014) } & \multirow{5}{*}{ Helianthus annuus } & M & CC & - & 6.6 \\
\hline & & & M & Chla/Chlb & - & 6.6 \\
\hline & & & M & ChlTot & - & 6.7 \\
\hline & & & । & LA & & 5.7 \\
\hline & & & I & SHDW & - & 5.2 \\
\hline & \multirow{2}{*}{ Scott-Fordsmand et al. (2000b) } & \multirow{2}{*}{ Eisenia fetida } & C & NRRT & 163 & - \\
\hline & & & I & CQ & 517 & - \\
\hline \multirow{3}{*}{$\mathrm{Zn}$} & \multirow{3}{*}{ Spurgeon et al. (2005) } & \multirow{3}{*}{ Lumbricus rubellus } & M & GE & 616 & \\
\hline & & & C & NRRT & 645 & - \\
\hline & & & । & CQ & 3236 & - \\
\hline
\end{tabular}

"Total" refers to total metal content in the soil, whereas $\mathrm{pMe}^{2+}$ refers to the negative logarithm of Me ${ }^{2+}$ ion activity, where $\mathrm{Me}^{2+}$ represents $\mathrm{Cu}^{2+}$ or $\mathrm{Zn}^{2+}$ ion. The lower value of $\mathrm{pMe}^{2+}$ signifies the higher activity of the free $\mathrm{Me}{ }^{2+}$ ion. LBO: Level of biological organization; M: molecular; C: cellular; I: individual; CC: carotenoid content; Chla/Chlb: chlorophyll a/chlorophyll b ratio; ChlTot: total chlorophyll content; CQ: cocoon quantity; GE: gene expression (mt-2); LA: leaf asymmetry; NRRT: neutral-red retention time; SH DW: shoot dry weight. 
et al. (2015), the authors correlated metal concentrations in earthworm tissues with earthworm responses. The conclusion was that the toxicity for Eisenia fetida in soils under study may be largely attributed to arsenic, whereas copper had only a secondary effect, contrary to what one would expect in soils affected by copper mining.

Another approach to sorting out the impacts of various metals in field-contaminated soils is to compare the obtained foliar metal concentrations with normal ranges. This approach was used to demonstrate that phytotoxicity in the Port Colborne site (Ontario, Canada) was attributable mostly to nickel, whereas the impacts of other metals (such as copper and cobalt) were minor (Dan et al., 2008, Kukier and Chaney 2004). In addition, a study by Hamels et al. (2014) evaluated the relative contribution of each individual metal to field-contaminated soil toxicity using a toxic unit approach. Specifically, for each metal, the toxic unit was calculated as the ratio of total metal concentration to the corresponding $\mathrm{EC}_{50}$ derived from single-metal spiked-soils for the same plant species.

However, there are several studies that have not demonstrated the effects of a single contaminant on biological responses (Appendices F-N). Thus, the data presented in these studies should be treated with caution. For this reason, we decided to exclude these studies from the summary in Table 2, considering only those studies that demonstrate the effects of a single contaminant on biological responses.

Interestingly, microorganisms are generally believed to be more sensitive to metals than plants and invertebrates
(Giller et al. 1999). However, our analysis reveals that there is no statistically significant difference between the sensitivity of microorganisms and other organisms (plants and invertebrates) to any metal or metal pool. Moreover, removing both low organization level responses (i.e., molecular and cellular) and high organization level responses (i.e., population, community, and ecosystem) from the analysis has almost no effect on the result (not shown).

It is important to emphasize that invertebrates are more sensitive to copper than plants, based on the total metal pool data. This is a strong argument in favor of using invertebrates as indicators of soil quality.

It is worth noting that zinc was less toxic than copper when judged by the soluble pool data. Measurements of total zinc content support this view, although there was only one available study of total zinc content. This finding is consistent with our own results, validating the alleviating effects of zinc on copper toxicity to plants and soil microorganisms in copper-polluted soils that are attributable to copper-zinc antagonism (Stowhas et al. 2018, Stuckey et al. 2021). As for nickel, the results are contradictory. Total pool data indicate that copper is more phytotoxic than nickel. While the statistical difference was significant at $a=0.1$, it is still valid given the high data variability.

However, soluble pool data suggest that nickel is more phytotoxic than copper $(p<0.001)$. The free ion activity data indicate the same trend as the soluble pool data, however, there was only one data for free $\mathrm{Ni}^{2+}$ ion activity. This

Table 2. Summary of effective concentrations $\left(\mathrm{EC}_{50}\right)$ for plants, invertebrates and microorganisms. For this summary, we considered only studies that demonstrates the impact of a single pollutant on biological responses

\begin{tabular}{|c|c|c|c|c|}
\hline Metal pool & Metal & Plants & Invertebrates & Microorganisms \\
\hline \multirow{5}{*}{$\begin{array}{c}\text { Total } \\
\left(\mathrm{mg} \mathrm{kg}^{-1}\right)\end{array}$} & As & - & 22 & 313 \\
\hline & $\mathrm{Cu}$ & $987 \pm 491 \mathrm{aB}^{*}$ & $303 \pm 108 b B^{* *}$ & $408 \pm 174 a b$ \\
\hline & $\mathrm{Ni}$ & $1710 \pm 510 A^{*}$ & - & - \\
\hline & $\mathrm{Pb}$ & - & $960 \pm 505 A^{* *}$ & - \\
\hline & $\mathrm{Zn}$ & 9820 & - & - \\
\hline \multirow{4}{*}{$\begin{array}{l}\text { Extractable } \\
\left(\mathrm{mg} \mathrm{kg}^{-1}\right)\end{array}$} & $\mathrm{Cu}$ & $330 \pm 520$ & - & 139 \\
\hline & $\mathrm{Ni}$ & 607 & - & - \\
\hline & $\mathrm{Pb}$ & - & $19 \pm 24$ & - \\
\hline & $\mathrm{Zn}$ & $1423 \pm 2059$ & - & - \\
\hline \multirow{4}{*}{$\begin{array}{l}\text { Soluble } \\
\left(\mu \mathrm{g} \mathrm{L}^{-1}\right)\end{array}$} & $\mathrm{Cu}$ & $382 \pm 213 B^{* * *}$ & - & - \\
\hline & $\mathrm{Ni}$ & $9.3 \pm 6.3 C^{* * *}$ & - & - \\
\hline & $\mathrm{Pb}$ & - & $24,784 \pm 37,159$ & - \\
\hline & $\mathrm{Zn}$ & $2579 \pm 270 A^{* * *}$ & - & $5971 \pm 4878$ \\
\hline \multirow{3}{*}{$\begin{array}{l}\text { Free ion activity } \\
\qquad\left(\mathrm{pMe}^{2+}\right)\end{array}$} & $\mathrm{Cu}$ & $6.1 \pm 0.3$ & - & - \\
\hline & $\mathrm{Ni}$ & 6.8 & - & - \\
\hline & $\mathrm{Zn}$ & - & - & - \\
\hline
\end{tabular}

The term "metal", for the sake of simplicity, includes metalloids (such as arsenic). pMe ${ }^{2+}$ refers to the negative logarithm of $\mathrm{Me}^{2+}$ ion activity, where $\mathrm{Me}^{2+}$ represents $\mathrm{Cu}^{2+}$ or $\mathrm{Ni}^{2+}$ ion. The lower value of $\mathrm{pMe}^{2+}$ signifies the higher activity of the free $\mathrm{Me}^{2+}$ ion. Lowercase letters in the same row indicate statistically significant differences between the types of organisms ( $p<0.05$ ). Uppercase letters in the same column for the same metal pool indicate significant differences between the metals $\left({ }^{*} p<0.1\right.$, $\left.{ }^{*} p<0.05,{ }^{* *} p<0.001\right)$. 
finding lends support to the study of Tarasova et al. (2020), which concluded that nickel impacted plant growth more severely than copper in $\mathrm{Cu}-\mathrm{Ni}$-smelter polluted soil.

\section{FUTURE RESEARCH NEEDS}

Although it is clear that scientific research should give preference to field-contaminated soils over spiked soils, a limited number of studies with field-contaminated soils have been conducted so far. As mentioned above, the biggest challenge in using field-collected soils for ecotoxicity assessment has to do with the presence of several metals in the polluted soil. In some cases, it might even be outright impossible to gauge the impact of any specific metal (e.g., Prudnikova et al. 2020).

We suggest that future research in this area should focus on contaminated sites with a single predominant metal contaminant. For example, historic industrial sites where wood has been treated with copper sulfate provide an excellent opportunity to encounter soils contaminated primarily with copper. One such site, located in Hygum, Denmark, has been extensively studied and copper toxicity thresholds for earthworms, and microorganisms have been established (e.g., Mirmonsef et al. 2017, Sauvé 2006). The Hygum site is believed to be polluted largely by copper
(Scott-Fordsmand et al., 2000b). Although the site has been the subject of several studies, none of them have shown explicitly that there are no other metals in the investigated soils. Given that arsenic- and chrome-based products were also common in wood preservation in the past (JakobsSchonwandt et al. 2010), additional soil chemical analysis at the Hygum site might be warranted. Since wood treatment with copper sulfate is a common practice around the world, we assume that historical wood treatment operations can be found in many other countries. Another possibility is to study copper toxicity in vineyards, where copper may be a major metal contaminant due to the use of copper sulfate as a fungicide (Schoffer et al. 2020).

There are other sites contaminated with one dominant metal contaminant that have been described in the literature but have not been sufficiently studied. For example, Al-Hiyaly et al. (1990) described a site with contamination from electric pylons where zinc could reasonably be assumed to be the dominant metal contaminant. However, the authors did not attempt to establish thresholds for zinc toxicity in that study. Thus, future studies at this and similar sites around the world should be encouraged.

\section{REFERENCES}

Al-Hiyaly S.A.K., McNeilly T., and Bradshaw A.D. (1990). The effect of zinc contamination from electricity pylons. Contrasting patterns of evolution in five grass species. New Phytologist 114, 183-190.

Aponte H., Mondaca P., Santander C., Meier S., Paolini J., Buttler B., Rojas C., Diez M.C., and Cornejo P. (2021). Enzyme activities and microbial functional diversity in metal (loid) contaminated soils near to a copper smelter. Science of The Total Environment, 146423, DOI: 10.1016/j.scitotenv.2021.146423.

Arthur E., Moldrup P., Holmstrup M., Schjonning P., Winding A., Mayer P., and de Jonge L.W. (2012). Soil microbial and physical properties and their relations along a steep copper gradient. Agriculture Ecosystems \& Environment, 159, 9-18, DOI: 10.1016/j.agee.2012.06.021.

Baath E., Arnebrant K., and Nordgren A. (1991). Microbial biomass and ATP in smelter-polluted forest humus. Bulletin of Environmental Contamination and Toxicology 47, 278-282, DOI: 10.1007/bf01688652.

Beyer W.N., Green C.E., Beyer M., and Chaney R.L. (2013). Phytotoxicity of zinc and manganese to seedlings grown in soil contaminated by zinc smelting. Environmental Pollution, 179, 167-176, DOI: 10.1016/j.envpol.2013.04.013.

Beyer W.N., Krafft C., Klassen S., Green C.E., and Chaney R.L. (2011). Relating injury to the forest ecosystem near Palmerton, PA, to zinc contamination from smelting. Archives of Environmental Contamination and Toxicology, 61, 376-388, DOI: 10.1007/s00244-010-9640-0.

Broos K., Beyens H., and Smolders E. (2005). Survival of rhizobia in soil is sensitive to elevated zinc in the absence of the host plant. Soil Biology \& Biochemistry, 37, 573-579, DOI: 10.1016/j.soilbio.2004.08.018.

Broos K., Uyttebroek M., Mertens J., and Smolders E. (2004). A survey of symbiotic nitrogen fixation by white clover grown on metal contaminated soils. Soil Biology \& Biochemistry, 36, 633-640, DOI: 10.1016/j.soilbio.2003.11.007.

Bustos V., Mondaca P., Sauvé S., Gaete H., Celis-Diez J.L., and Neaman A. (2015). Thresholds of arsenic toxicity to Eisenia fetida in fieldcollected agricultural soils exposed to copper mining activities in Chile. Ecotoxicology and Environmental Safety, 122, 448-454, DOI: 10.1016/j. ecoenv.2015.09.009.

Checkai R., Van Genderen E., Sousa J.P., Stephenson G., and Smolders E. (2014). Deriving site-specific clean-up criteria to protect ecological receptors (plants and soil invertebrates) exposed to metal or metalloid soil contaminants via the direct contact exposure pathway. Integrated Environmental Assessment and Management, 10, 346-357, DOI: 10.1002/ieam.1528.

Cioccio S., Gopalapillai Y., Dan T., and Hale B. (2017). Effect of liming on nickel bioavailability and toxicity to oat and soybean grown in field soils containing aged emissions from a nickel refinery. Environmental Toxicology and Chemistry, 36, 1110-1119, DOI: 10.1002/etc.3634.

Dan T., Hale B., Johnson D., Conard B., Stiebel B., and Veska E. (2008). Toxicity thresholds for oat (Avena sativa L.) grown in Ni-impacted agricultural soils near Port Colborne, Ontario, Canada. Canadian Journal of Soil Science, 88, 389-398, DOI: 10.4141/CJSS07070

De Knecht J.A., Hooftman R.N., Kaag N.H.B.M., van der Hoeven N., and Henzen L. (1998). Effects of zinc on the germination and growth of red clover, Trifolium pratense, under field and laboratory conditions, In: Posthuma L., Van Gestel C. A. M., Smit CE B. D. and Vonk J. W., (Eds.), Validation of toxicity data and risk limits for soils. Report n607505004. Bilthoven, The Netherlands: National Institute of Public Health and The Environment, 67-77.

Delgadillo V., Verdejo J., Mondaca P., Verdugo G., Gaete H., Hodson M.E., and Neaman A. (2017). Proposed modification to avoidance test with Eisenia fetida to assess metal toxicity in agricultural soils affected by mining activities. Ecotoxicology and Environmental Safety 140 , 230-234, DOI: 10.1016/j.ecoenv.2017.02.038.

Ford R.G., Bertsch P.M., and Farley K.J. (1997). Changes in transition and heavy metal partitioning during hydrous iron oxide aging. Environmental Science \& Technology, 31, 2028-2033, DOI: 10.1021/es960824+.

Giller K.E., Witter E., and McGrath S.P. (1999). Assessing risks of heavy metal toxicity in agricultural soils: Do microbes matter? Human and Ecological Risk Assessment, 5, 683-689, DOI: 10.1080/10807039.1999.9657732. 
Gopalapillai Y., Dan T., and Hale B. (2019). Ni bioavailability in oat (Avena sativa) grown in naturally aged, Ni refinery-impacted agricultural soils. Human and Ecological Risk Assessment, 25, 1422-1437, DOl: 10.1080/10807039.2018.1464382.

Hamels F., Malevé J., Sonnet P., Kleja D.B., and Smolders E. (2014). Phytotoxicity of trace metals in spiked and field-contaminated soils: Linking soil-extractable metals with toxicity. Environmental Toxicology and Chemistry, 33, 2479-2487, DOI: 10.1002/etc.2693.

Hooper M., and Anderson M. (2008). Soil Toxicity and Bioassessment Test Methods for Ecological Risk Assessment: Toxicity Test Methods for Soil Microorganisms, Terrestrial Plants, Terrestrial Invertebrates and Terrestrial Vertebrates. Office of Environmental Health Hazard Assessment, California Environmental Protection Agency.

Hui N., Selonen S., Hanzel J., Tuomela M., Rainio A., Kontio H., Hakala K., Lankinen P., Steffen K., Fingerroos T., Strommer R., Setala H., Hatakka A., and Romantschuk M. (2009). Influence of lead on organisms within the detritus food web of a contaminated pine forest soil. Boreal Environment Research 14, 70-85.

Jakobs-Schonwandt D., Mathies H., Abraham W.R., Pritzkow W., Stephan I., and Noll M. (2010). Biodegradation of a Biocide (Cu-NCyclohexyldiazenium Dioxide) Component of a Wood Preservative by a Defined Soil Bacterial Community. Applied and Environmental Microbiology, 76, 8076-8083, DOI: 10.1128/aem.01092-10.

Kolbas A., Kolbas N., Marchand L., Herzig R., and Mench M. (2018). Morphological and functional responses of a metal-tolerant sunflower mutant line to a copper-contaminated soil series. Environmental Science and Pollution Research, 25, 16686-16701, DOI: 10.1007/s11356-018$1837-1$.

Kolbas A., Marchand L., Herzig R., Nehnevajova E., and Mench M. (2014). Phenotypic seedling responses of a metal-tolerant mutant line of sunflower growing on a Cu-contaminated soil series: potential uses for biomonitoring of Cu exposure and phytoremediation. Plant and Soil, 376, 377-397, DOI: 10.1007/s11104-013-1974-8.

Konečný L., Ettler V., Kristiansen S., Barros Amorim M.J., Kříbek B., Mihaljevič M., Šebek O., Nyambe I., and Scott-Fordsmand J. (2014). Response of Enchytraeus crypticus worms to high metal levels in tropical soils polluted by copper smelting. Journal of Geochemical Exploration, 144, 427-432, DOI: 10.1016/j.gexplo.2013.10.004.

Korkina I.N., and Vorobeichik E.L. (2018). Humus Index as an indicator of the topsoil response to the impacts of industrial pollution. Applied Soil Ecology, 123, 455-463, DOI: 10.1016/j.apsoil.2017.09.025.

Kukier U., and Chaney R.L. (2004). In situ remediation of nickel phytotoxicity for different plant species. Journal of Plant Nutrition, 27, 465-495, DOI: 10.1081/pln-120028874.

Lessard I., Sauve S., and Deschenes L. (2014a). Enzymatic functional stability of Zn-contaminated field-collected soils: An ecotoxicological perspective. Science of the Total Environment, 484, 1-9, DOI: 10.1016/j.scitotenv.2014.03.024.

Lessard I., Sauve S., and Deschenes L. (2014b). Toxicity response of a new enzyme-based functional diversity methodology for Zncontaminated field-collected soils. Soil Biology \& Biochemistry, 71, 87-94, DOI: 10.1016/j.soilbio.2014.01.002.

Lillo-Robles F., Tapia-Gatica J., Díaz-Siefer P., Moya H., Celis-Diez J.L., Santa Cruz J., Ginocchio R., Sauvé S., Brykov V.A., and Neaman A. (2020). Which soil Cu pool governs phytotoxicity in field-collected soils contaminated by copper smelting activities in central Chile? Chemosphere, 242, 125176, DOI: 10.1016/j.chemosphere.2019.125176.

Liu M.P., Xu J., Krogh P.H., Song J., Wu L.H., Luo Y.M., and Ke X. (2018). Assessment of toxicity of heavy metal-contaminated soils toward Collembola in the paddy fields supported by laboratory tests. Environmental Science and Pollution Research, 25, 16969-16978, DOI: 10.1007/ s11356-018-1864-y.

Luo W., Verweij R.A., and van Gestel C.A.M. (2014a). Contribution of soil properties of shooting fields to lead biovailability and toxicity to Enchytraeus crypticus. Soil Biology \& Biochemistry, 76, 235-241, DOI: 10.1016/j.soilbio.2014.05.023.

Luo W., Verweij R.A., and van Gestel C.A.M. (2014b). Determining the bioavailability and toxicity of lead contamination to earthworms requires using a combination of physicochemical and biological methods. Environmental Pollution, 185, 1-9, DOl: 10.1016/j.envpol.2013.10.017. Luo W., Verweij R.A., and van Gestel C.A.M. (2015). Toxicity of Pb contaminated soils to the oribatid mite Platynothrus peltifer. Ecotoxicology, 24, 985-990, DOI: 10.1007/s10646-015-1439-3.

Maraldo K., Christensen B., Strandberg B., and Holmstrup M. (2006). Effects of copper on enchytraeids in the field under differing soil moisture regimes. Environmental Toxicology and Chemistry, 25, 604-612, DOI: 10.1897/05-076R.1.

Marschner H. (1993). Zinc Uptake from Soils, In: Robson A. D., editor Zinc in Soils and Plants. Dordrecht, The Netherlands: Kluwer Academic, 59-77.

Martinez C.E., and Martinez-Villegas N. (2008). Copper-alumina-organic matter mixed systems: Alumina transformation and copper speciation as revealed by EPR Spectroscopy. Environmental Science \& Technology, 42, 4422-4427, DOI: 10.1021/es703206u.

McBride M.B., and Cai M.F. (2016). Copper and zinc aging in soils for a decade: changes in metal extractability and phytotoxicity. Environmental Chemistry, 13, 160-167, DOI: 10.1071/en15057.

Mertens J., and Smolders E. (2013). Zinc, In: Alloway B. J., editor Heavy metals in soils: trace metals and metalloids in soils and their bioavailability. Dordrecht: Springer Science \& Business Media, 465-493, DOI: 10.1007/978-94-007-4470-7_17.

Mertens J., Wakelin S.A., Broos K., McLaughlin M.J., and Smolders E. (2010). Extent of copper tolerance and consequences for functional stability of the ammonia-oxidizing community in long-term copper-contaminated soils. Environmental Toxicology and Chemistry, 29, 2737, DOI: 10.1002 /etc.16.

Mirmonsef H., Hornum H.D., Jensen J., and Holmstrup M. (2017). Effects of an aged copper contamination on distribution of earthworms, reproduction and cocoon hatchability. Ecotoxicology and Environmental Safety, 135, 267-275, DOI: 10.1016/j.ecoenv.2016.10.012.

Mondaca P., Catrin J., Verdejo J., Sauvé S., and Neaman A. (2017). Advances on the determination of thresholds of Cu phytotoxicity in field-contaminated soils in central Chile. Environmental Pollution, 223, 146-152, DOl: 10.1016/j.envpol.2016.12.076.

Nahmani J., and Lavelle P. (2002). Effects of heavy metal pollution on soil macrofauna in a grassland of Northern France. European Journal of Soil Biology, 38, 297-300, DOl: 10.1016/s1164-5563(02)01169-x.

Naveed M., Moldrup P., Arthur E., Holmstrup M., Nicolaisen M., Tuller M., Herath L., Hamamoto S., Kawamoto K., Komatsu T., Vogel H.J., and de Jonge L.W. (2014). Simultaneous Loss of Soil Biodiversity and Functions along a Copper Contamination Gradient: When Soil Goes to Sleep. Soil Science Society of America Journal, 78, 1239-1250, DOI: 10.2136/sssaj2014.02.0052.

Neaman A., Selles I., Martínez C.E., and Dovletyarova E.A. (2020). Analyzing soil metal toxicity: Spiked or field-contaminated soils? Environmental Toxicology and Chemistry, 39, 513-514, DOI: 10.1002/etc.4654.

Neaman A., Verdejo J., Ramírez M., and Pinochet D. (2021). Phytoextraction of metals from contaminated soils: Chance or utopia? Agro Sur, 49, 1-4, DOI: 10.4206/agrosur.2021.v49n1-01. 
Nolan A.L., Zhang H., and McLaughlin M.J. (2005). Prediction of zinc, cadmium, lead, and copper availability to wheat in contaminated soils using chemical speciation, diffusive gradients in thin films, extraction, and isotopic dilution techniques. Journal of Environmental Quality, 34, 496-507, DOI: 10.2134/jeq2005.0496.

Nordgren A., Kauri T., Baath E., and Soderstrom B. (1986). Soil microbial activity, mycelial lengths and physiological groups of bacteria in a heavy metal polluted area. Environmental Pollution Series a-Ecological and Biological, 41, 89-100, DOl: 10.1016/0143-1471(86)90108-x.

Posthuma L., and Notenboom J. (1996). Toxic effects of heavy metals in three worm species exposed in artificially contaminated soil substrates and contaminated field soils. Report $n^{\circ} 719102048$. Bilthoven, The Netherlands: National Institute of Public Health and The Environment.

Prudnikova E.V., Neaman A., Terekhova V.A., Karpukhin M.M., Vorobeichik E.L., Smorkalov I.A., Dovletyarova E.A., Navarro-Villarroel C., Ginocchio R., and Peñaloza P. (2020). Root elongation method for the quality assessment of metal-polluted soils: Whole soil or soil-water extract? Journal of Soil Science and Plant Nutrition, 20, 2294-2303, DOI: 10.1007/s42729-020-00295-x.

Santa-Cruz J., Vasenev I.I., Gaete H., Penaloza P., Krutyakov Y.A., and Neaman A. (2021). Metal Ecotoxicity Studies with Artificially Contaminated versus Anthropogenically Contaminated Soils: Literature Review, Methodological Pitfalls and Research Priorities. Russian Journal of Ecology (accepted).

Sauvé S. (2002). Speciation of Metals in Soils, In: Allen H. E., editor Bioavailability of Metals in Terrestrial Ecosystems: Importance of Partitioning for Bioavailability to Intervebrates, Microbes, and Plants. Pensacola, Florida: Society of Environmental Toxicology and Chemistry (SETAC), 7-37.

Sauvé S. (2006). Copper inhibition of soil organic matter decomposition in a seventy-year field exposure. Environmental Toxicology and Chemistry, 25, 854-857, DOl: 10.1897/04-575R.1.

Sauvé S., Cook N., Hendershot W.H., and McBride M.B. (1996). Linking plant tissue concentrations and soil copper pools in urban contaminated soils. Environmental Pollution, 94, 153-157,DOl: 10.1016/S0269-7491(96)00081-4.

Schoffer J.T., Sauvé S., Neaman A., and Ginocchio R. (2020). Role of leaf litter on the incorporation of copper-containing pesticides into soils under fruit production: A review. Journal of Soil Science and Plant Nutrition, 20, 990-1000, DOI: 10.1007/s42729-020-00186-1.

Scott-Fordsmand J.J., Krogh P.H., and Weeks J.M. (2000a). Responses of Folsomia fimetaria (Collembola: Isotomidae) to copper under different soil copper contamination histories in relation to risk assessment. Environmental Toxicology and Chemistry, 19, 1297-1303, DOI: 10.1002/etc.5620190511.

Scott-Fordsmand J.J., Weeks J.M., and Hopkin S.P. (2000b). Importance of contamination history for understanding toxicity of copper to earthworm Eisenia fetida (Oligochaeta: Annelida), using neutral-red retention assay. Environmental Toxicology and Chemistry, 19, 1774-1780, DOI: 10.1897/1551-5028(2000)019<1774:iochfu>2.3.co;2.

Smolders E., Buekers J., Waegeneers N., Oliver I., and McLaughlin M.J. (2002). Effects of field and laboratory Zn contamination on soil microbial processes and plant growth. Final report to the International Lead and Zinc Research Organization (ILZRO).

Spurgeon D., and Hopkin S. (1995). Extrapolation of the laboratory-based OECD earthworm toxicity test to metal-contaminated field sites. Ecotoxicology, 4, 190-205, DOI: 10.1007/BF00116481.

Spurgeon D.J., and Hopkin S.P. (1996). Effects of metal-contaminated soils on the growth, sexual development, and early cocoon production of the earthworm Eisenia fetida, with particular reference to zinc. Ecotoxicology and Environmental Safety, 35, 86-95, DOl: 10.1006/eesa.1996.0085.

Spurgeon D.J., Ricketts H., Svendsen C., Morgan A.J., and Kille P. (2005). Hierarchical responses of soil invertebrates (earthworms) to toxic metal stress. Environmental Science \& Technology, 39, 5327-5334, DOI: 10.1021/es050033k.

Stowhas T., Verdejo J., Yáñez C., Celis-Diez J.L., Martínez C.E., and Neaman A. (2018). Zinc alleviates copper toxicity to symbiotic nitrogen fixation in agricultural soil affected by copper mining in central Chile. Chemosphere, 209 960-963, DOI: 10.1016/j.chemosphere.2018.06.166.

Stuckey J.W., Neaman A., Verdejo J., Navarro-Villarroel C., Peñaloza P., and Dovletyarova E.A. (2021). Zinc alleviates copper toxicity to lettuce and oat in copper contaminated soils. Journal of Soil Science and Plant Nutrition, DOI: 10.1007/s42729-021-00435-x.

Tarasova E., Drogobuzhskaya S., Tapia-Pizarro F., Morev D.V., Brykov V.A., Dovletyarova E.A., Slukovskaya M., Navarro-Villarroel C., Paltseva A.A., and Neaman A. (2020). Vermiculite-lizardite industrial wastes promote plant growth in a peat soil affected by a Cu/Ni smelter: a case study at the Kola Peninsula, Russia. Journal of Soil Science and Plant Nutrition, 20, 1013-1018, DOI: 10.1007/s42729-020-00188-z.

van Gestel C.A.M. (2012). Soil ecotoxicology: state of the art and future directions. Zookeys, 275-296, DOI: 10.3897/zookeys.176.2275.

Van Zwieten L., Rust J., Kingston T., Merrington G., and Morris S. (2004). Influence of copper fungicide residues on occurrence of earthworms in avocado orchard soils. Science of the Total Environment, 329, 29-41, DOI: 10.1016/j.scitotenv.2004.02.014.

Vanhala P.T., and Ahtiainen J.H. (1994). Soil respiration, ATP content, and Photobacterium toxicity test as indicators of metal pollution in soil. Environmental Toxicology and Water Quality, 9, 115-121, DOI: 10.1002/tox.2530090207.

Verdejo J., Ginocchio R., Sauvé S., Mondaca P., and Neaman A. (2016). Thresholds of copper toxicity to lettuce in field-collected agricultural soils exposed to copper mining activities in Chile. Journal of Soil Science and Plant Nutrition, 16, 154-158, DOI: 10.4067/S071895162016005000011.

Verdejo J., Ginocchio R., Sauvé S., Salgado E., and Neaman A. (2015). Thresholds of copper phytotoxicity in field-collected agricultural soils exposed to copper mining activities in Chile. Ecotoxicology and Environmental Safety, 122, 171-177, DOI: 10.1016/j.ecoenv.2015.07.026.

Wang Z.Q., Tian H.X., Lei M., Megharaj M., Tan X.P., Wang F., Jia H.Z., and He W.X. (2020). Soil enzyme kinetics indicate ecotoxicity of longterm arsenic pollution in the soil at field scale. Ecotoxicology and Environmental Safety, 191, DOI: 10.1016/j.ecoenv.2020.110215. 
Appendix

Appendix A. Correlation coefficients between different arsenic soil pools and biological responses

\begin{tabular}{|c|c|c|c|c|c|}
\hline Study & Coefficient & Species & Endpoint & $A s_{\text {total }}$ & $\mathrm{As}_{\text {soluble }}$ \\
\hline \multirow{6}{*}{ Wang et al. (2020) } & \multirow{6}{*}{ Pearson (r) } & \multirow{6}{*}{ Native microbes } & $\mathrm{ACP} \mathrm{K}_{\mathrm{a}}$ & $-0.70^{* *}$ & -0.49 \\
\hline & & & $A C P V_{\max }$ & $-0.70^{*}$ & $-0.70^{*}$ \\
\hline & & & $\mathrm{BG} \mathrm{K}_{\mathrm{a}}$ & $-0.49^{*}$ & ns \\
\hline & & & $B G V_{\text {max }}$ & $-0.70^{*}$ & ns \\
\hline & & & $\mathrm{DHAK}_{\mathrm{a}}$ & ns & $-0.70^{*}$ \\
\hline & & & $D H A V_{\max }$ & $-0.70^{*}$ & $-0.70^{*}$ \\
\hline
\end{tabular}

Significance level: ${ }^{*} p<0.05,{ }^{* *} p<0.01$, ns: not significant. ACP $K_{a}$ : acid phosphatase catalytic efficiency; ACP $V_{\text {max }}$ : acid phosphatase maximum reaction rate; ALP $K_{a}$ : alkaline phosphatase catalytic efficiency; ALP $V_{\text {max: }}$ alkaline phosphatase maximum reaction rate; $B G K_{a}$ : $\beta$-glucosidase catalytic efficiency; $B G V_{\text {max }}$ : $\beta$-glucosidase maximum reaction rate; $D H A$ K dehydrogenase catalytic efficiency; $\mathrm{DHA}_{\max }$ : dehydrogenase maximum reaction rate.

Appendix B. Correlation coefficients between different copper soil pools and biological responses

\begin{tabular}{|c|c|c|c|c|c|c|c|}
\hline Study & Coefficient & Species & Endpoint & $\mathrm{Cu}_{\text {total }}$ & $\mathrm{Cu}_{\text {extractable }}$ & $\mathrm{Cu}_{\text {soluble }}$ & $\mathrm{pCu}^{2+}$ \\
\hline \multirow{7}{*}{ Kolbas et al. (2014) } & \multirow{7}{*}{ Pearson (r) } & \multirow{7}{*}{$\begin{array}{l}\text { Helianthus annuus } \\
\text { (Sunflower) }\end{array}$} & CC & $-0.88^{* * *}$ & - & $-0.91^{* * *}$ & $0.89 * * *$ \\
\hline & & & Chla/Chlb & ns & - & ns & $0.51^{* *}$ \\
\hline & & & ChlTot & $-0.89 * * *$ & - & $-0.91^{* * *}$ & $0.89^{* * *}$ \\
\hline & & & $\mathrm{LL}$ & $-0.37^{*}$ & - & $-0.36^{*}$ & $0.64^{* *}$ \\
\hline & & & R DW & $-0.79 * * *$ & - & $-0.81 * * *$ & $0.76^{* * *}$ \\
\hline & & & SHDW & $-0.56^{* *}$ & - & $-0.51^{* *}$ & $0.62^{* *}$ \\
\hline & & & TLA & $-0.44^{*}$ & - & $-0.41^{*}$ & $0.55^{* *}$ \\
\hline Konečný et al. (2014) & Spearman $(\rho)$ & $\begin{array}{l}\text { Enchytraeus } \\
\text { crypticus }\end{array}$ & $J Q$ & $-0.97^{* * *}$ & $-0.89 * * *$ & - & - \\
\hline \multirow{5}{*}{ Kolbas et al. (2018) } & \multirow{5}{*}{ Pearson (r) } & \multirow{5}{*}{$\begin{array}{l}\text { Helianthus annuus } \\
\text { (Sunflower) }\end{array}$} & ChlTot & ns & - & ns & - \\
\hline & & & RDW & $-0.81^{* *}$ & - & $-0.85^{* *}$ & - \\
\hline & & & SHDW & $-0.86^{* *}$ & - & $-0.94^{* *}$ & - \\
\hline & & & TAC & ns & - & ns & - \\
\hline & & & TLA & $-0.84^{* *}$ & - & $-0.92^{* *}$ & - \\
\hline
\end{tabular}

Significance level: ${ }^{*} p<0.05,{ }^{* *} p<0.01,{ }^{* * *} p<0.001$, ns: not significant. CC: carotenoid content; Chla/Chlb: chlorophyll a/ chlorophyll b ratio; ChlTot: total chlorophyll content; EL: epicotyl length; JQ: juvenile quantity; LA: leaf asymmetry; LL: leaf length; R DW: root dry weight; SH DW: shoot dry weight; SH L: shoot length; TAC: total antioxidant capacity; TLA: total leaf area; WC: water content. 
Appendix C. Determination coefficients $\left(R^{2}\right)$ of regressions between different copper soil pools and biological responses

\begin{tabular}{|c|c|c|c|c|c|c|}
\hline Study & Species & Endpoint & $\mathrm{Cu}_{\text {total }}$ & $\mathrm{Cu}_{\text {extractable }}$ & $\mathrm{Cu}_{\text {soluble }}$ & $\mathrm{pCu}^{2+}$ \\
\hline Konečný et al. (2014) & Enchytraeus crypticus & $J Q$ & $0.93^{*}$ & $0.80^{*}$ & - & - \\
\hline \multirow{2}{*}{ Verdejo et al. (2015) } & \multirow{2}{*}{$\begin{array}{l}\text { Lolium perenne } \\
\text { (Perennial ryegrass) }\end{array}$} & $R L$ & $0.40^{*}$ & - & $0.40^{*}$ & $0.33^{*}$ \\
\hline & & $\mathrm{SHL}$ & $0.58^{*}$ & - & $0.24^{*}$ & ns \\
\hline Verdejo et al. (2016) & Lactuca sativa (Lettuce) & $\mathrm{SHL}$ & $0.19^{*}$ & - & ns & ns \\
\hline \multirow{10}{*}{ Mondaca et al. (2017) } & \multirow{4}{*}{$\begin{array}{c}\text { Avena sativa } \\
\text { (Oat) }\end{array}$} & $\mathrm{SH} \mathrm{L}^{\mathrm{a}}$ & $0.36^{*}$ & - & ns & ns \\
\hline & & RDW & $0.36^{*}$ & - & ns & ns \\
\hline & & SHDW & $0.44^{*}$ & - & ns & ns \\
\hline & & $\mathrm{SH} L^{c}$ & $0.35^{*}$ & - & $0.20^{*}$ & $0.19^{*}$ \\
\hline & \multirow{6}{*}{$\begin{array}{c}\text { Brassica rapa } \\
\text { (Turnip) }\end{array}$} & SHDWa & $0.46^{*}$ & - & ns & ns \\
\hline & & SH La & $0.47^{*}$ & - & ns & ns \\
\hline & & $R L$ & $0.67^{*}$ & - & ns & ns \\
\hline & & SHDW ${ }^{b}$ & $0.67^{*}$ & - & $0.27^{*}$ & ns \\
\hline & & $\mathrm{SH} L^{b}$ & $0.64^{*}$ & - & $0.31^{*}$ & ns \\
\hline & & $\mathrm{SPQ}$ & $0.56^{*}$ & - & $0.19^{*}$ & ns \\
\hline \multirow{3}{*}{ Lillo-Robles et al. (2020) } & \multirow{3}{*}{ Several species } & PC & ns & - & $0.67^{*}$ & ns \\
\hline & & SHDW & ns & - & $0.99^{* *}$ & $0.69^{*}$ \\
\hline & & SR & ns & - & $0.78^{*}$ & ns \\
\hline
\end{tabular}

Significance level: ${ }^{*} p<0.05,{ }^{* *} p<0.001$, ns: not significant. Test duration: ${ }^{a} 21$ days, ${ }^{\text {b }} 42$ days, ${ }^{c} 62$ days. JQ: juvenile quantity; PC: plant cover; R DW: root dry weight; R L: root length; SH DW: shoot dry weight; SH L: shoot length; SPQ: seeds pods quantity; SR: species richness.

Appendix D. Correlation coefficients between different lead soil pools and biological responses

\begin{tabular}{|c|c|c|c|c|c|c|c|}
\hline \multirow{2}{*}{ Study } & \multirow{2}{*}{ Coefficient } & \multirow{2}{*}{ Species } & \multirow{2}{*}{ Endpoint } & \multirow{2}{*}{$\mathrm{Pb}_{\text {total }}$} & \multicolumn{2}{|c|}{$\mathrm{Pb}_{\text {extractable }}$} & \multirow{2}{*}{$\mathrm{Pb}_{\text {soluble }}$} \\
\hline & & & & & $0.01 \mathrm{M} \mathrm{CaCl}_{2}$ & Water & \\
\hline \multirow{2}{*}{ Luo et al. (2014b) } & \multirow{2}{*}{ Pearson (r) } & \multirow{2}{*}{ Eisenia andrei } & SV & $-0.68^{*}$ & $-0.83^{*}$ & $-0.79 *$ & $-0.78^{*}$ \\
\hline & & & $J Q$ & ns & $-0.63^{*}$ & $-0.47^{*}$ & $-0.52^{*}$ \\
\hline \multirow{2}{*}{ Luo et al. (2014a) } & \multirow{2}{*}{ Pearson (r) } & \multirow{2}{*}{ Enchytraeus crypticus } & SV & $-0.65^{*}$ & $-0.87^{*}$ & $-0.72^{*}$ & $-0.82^{*}$ \\
\hline & & & $J Q$ & $-0.63^{*}$ & $-0.81^{*}$ & $-0.73^{*}$ & $-0.85^{*}$ \\
\hline Luo et al. (2015) & Pearson (r) & Platynothrus peltifer & $J Q$ & ns & $-0.49^{*}$ & $-0.45^{*}$ & $-0.44^{*}$ \\
\hline
\end{tabular}

Significance level: * $p<0.01$, ns: not significant. JQ: juvenile quantity; SV: survival. 
Appendix E. Correlation coefficients between different fractions of zinc in soil and biological responses

\begin{tabular}{|c|c|c|c|c|c|c|}
\hline \multirow{2}{*}{ Study } & \multirow{2}{*}{ Coefficient } & \multirow{2}{*}{ Species } & \multirow{2}{*}{ Endpoint } & \multirow{2}{*}{$\mathrm{Zn}_{\text {total }}$} & \multicolumn{2}{|c|}{$Z n_{\text {soluble }}$} \\
\hline & & & & & $0.01 \mathrm{M} \mathrm{KNO}_{3}$ & ASV \\
\hline \multirow{6}{*}{ Lessard et al. (2014b) } & \multirow{6}{*}{ Not available } & \multirow{6}{*}{ Native microbes } & AA & ns & $-0.87^{* *}$ & $-0.89^{* *}$ \\
\hline & & & $B G A$ & ns & ns & $-0.70^{*}$ \\
\hline & & & IA & ns & $-0.80^{* *}$ & $-0.81^{* *}$ \\
\hline & & & $\mathrm{PHA}$ & ns & $-0.84^{* *}$ & $-0.87^{* *}$ \\
\hline & & & PA & ns & $-0.78^{*}$ & $-0.80^{* *}$ \\
\hline & & & UA & ns & $-0.85^{* *}$ & $-0.87^{* *}$ \\
\hline
\end{tabular}

Significance level: ${ }^{*} p<0.05,{ }^{* *} p<0.01$. AA: arylsulfatase activity; ASV: $0.01 \mathrm{M} \mathrm{KNO}_{3}$ extract measured by square wave anodic stripping voltammetry; BG A: $\beta$-glucosidase activity; IA: invertase activity; PA: protease activity; PH A: phosphatase activity; UA: urease activity.

\section{Appendix F. Total effective concentrations (ECX) of arsenic and the properties of soils under study}

\begin{tabular}{|c|c|c|c|c|c|c|c|c|c|c|}
\hline \multirow{2}{*}{ Study } & \multirow{2}{*}{ SO } & \multicolumn{3}{|c|}{ Soil properties } & \multirow{2}{*}{ M } & \multirow{2}{*}{$\mathrm{D}$} & \multirow{2}{*}{ Species } & \multicolumn{3}{|c|}{$A s_{\text {total }}\left(\mathrm{mg} \mathrm{kg}^{-1}\right)$} \\
\hline & & $\mathrm{pH}$ & $\mathrm{CEC}\left(\mathrm{cmol}_{+} \mathrm{kg}^{-1}\right)$ & OM (\%) & & & & $\mathrm{EC}_{10}$ & $\mathrm{EC}_{25}$ & $\mathrm{EC}_{50}$ \\
\hline \multicolumn{11}{|c|}{ Invertebrates: Worms } \\
\hline Bustos et al. (2015) & Chile & $5.7-7.6$ & NA & $0.7-4.9$ & VS & $\sqrt{ }$ & Eisenia fetida & 8 & 14 & 22 \\
\hline \multicolumn{11}{|c|}{ Microorganisms } \\
\hline Nordgren et al. (1986) & Sweden & $3.5-5.0$ & NA & NA & VS & $x$ & Native microbes & - & - & 200 \\
\hline Wang et al. (2020) & China & $4.6-8.2$ & $8.1-22$ & $0.5-5.3$ & VS & $\sqrt{ }$ & Native microbes & 35 & - & 313 \\
\hline & & & & & & & Microbe mean & 35 & - & 257 \\
\hline
\end{tabular}

CEC: cation exchange capacity; D: the study demonstrates the impact of a single pollutant on biological responses?; " $x$ " means "no", whereas " $\sqrt{ }$ " means "yes"; M: method; VS: various field-collected soils; native microbes: biological response is attributed to several soil microorganism taxa (i.e., archaea, bacteria, actinomycete, algae, fungi, and protozoa); NA: not available; OM: organic matter; SO: soil origin. 
Appendix $\mathrm{G}$. Total effective concentrations $\left(E C_{x}\right)$ of copper and the properties of soils under study

\begin{tabular}{|c|c|c|c|c|c|c|c|c|c|c|}
\hline \multirow{2}{*}{ Study } & \multirow{2}{*}{ SO } & \multicolumn{3}{|c|}{ Soil properties } & \multirow{2}{*}{$M$} & \multirow{2}{*}{$\mathrm{D}$} & \multirow{2}{*}{ Species } & \multicolumn{3}{|c|}{$\mathrm{Cu}_{\text {total }}\left(\mathrm{mg} \mathrm{kg}^{-1}\right)$} \\
\hline & & $\mathrm{pH}$ & $\mathrm{CEC}\left(\mathrm{cmol}_{+} \mathrm{kg}^{-1}\right)$ & $\mathrm{OM}(\%)$ & & & & $\mathrm{EC}_{10}$ & $\mathrm{EC}_{25}$ & $\mathrm{EC}_{50}$ \\
\hline \multicolumn{11}{|c|}{ Plants } \\
\hline Hamels et al. (2014) & Sweden & $5.0-6.1$ & $9-16$ & 12.1 & $\mathrm{~F}$ & $\sqrt{ }$ & $\begin{array}{l}\text { Hordeum vulgare } \\
\text { (Barley) }\end{array}$ & - & - & 1260 \\
\hline Kolbas et al. (2014) & France & $7.0-7.5$ & $3.1-19$ & $1.5-7.8$ & VS & $\sqrt{ }$ & $\begin{array}{l}\text { Helianthus annuus } \\
\text { (Sunflower) }\end{array}$ & 372 & - & 760 \\
\hline Verdejo et al. (2015) & Chile & $5.7-7.6$ & NA & $0.7-5.8$ & VS & $\sqrt{ }$ & $\begin{array}{l}\text { Lolium perenne } \\
\text { (Perennial ryegrass) }\end{array}$ & 414 & 750 & 1088 \\
\hline Verdejo et al. (2016) & Chile & $5.7-7.6$ & NA & $0.7-5.8$ & VS & $\sqrt{ }$ & Lactuca sativa (Lettuce) & 445 & 955 & 1805 \\
\hline Mondaca et al. (2017) & Chile & $5.7-7.6$ & NA & $0.7-5.8$ & VS & $\sqrt{ }$ & Several species & 421 & 618 & 840 \\
\hline Kolbas et al. (2018) & France & $5.9-7.2$ & $2.7-3.2$ & $1.2-1.5$ & $\mathrm{~F}$ & $\sqrt{ }$ & $\begin{array}{l}\text { Helianthus annuus } \\
\text { (Sunflower) }\end{array}$ & 145 & - & 318 \\
\hline & & & & & & & Plant mean & 369 & 735 & 987 \\
\hline \multicolumn{11}{|c|}{ Invertebrates } \\
\hline \multicolumn{11}{|c|}{ a. Nematodes } \\
\hline Naveed et al. (2014) & Denmark & $5.9-6.6$ & NA & $3.3-6.0$ & VS & $\sqrt{ }$ & Native nematodes & 338 & - & - \\
\hline \multicolumn{11}{|c|}{ b. Springtails } \\
\hline \multirow{2}{*}{ Scott-Fordsmand et al. (2000a) } & \multirow{2}{*}{ Denmark } & \multirow{2}{*}{$6.1-7.1$} & \multirow{2}{*}{$10-13$} & \multirow{2}{*}{$3.9-5.5$} & \multirow{2}{*}{ VS } & \multirow{2}{*}{$\sqrt{ }$} & \multirow{2}{*}{ Folsomia fimetaria } & 643 & - & - \\
\hline & & & & & & & & $2463^{c}$ & - & - \\
\hline Liu et al. (2018) & China & 7.2 & 18 & 3.2 & VS & $x$ & Several species & 187 & - & 723 \\
\hline & & & & & & & Springtail mean & 278 & - & 723 \\
\hline \multicolumn{11}{|c|}{ c. Worms } \\
\hline Scott-Fordsmand et al. (2000b) & Denmark & $6.5-7.0$ & NA & NA & VS & $\sqrt{ }$ & Eisenia fetida & 159 & - & 340 \\
\hline Van Zwieten et al. (2004) & Australia & $6.6-6.9$ & NA & $3.3-12$ & $\mathrm{~F}$ & $x$ & Eisenia fetida & - & - & $131 a$ \\
\hline Maraldo et al. (2006) & Denmark & NA & NA & NA & VS & $\sqrt{ }$ & Enchytraeus crypticus & 99 & - & 439 \\
\hline Konečný et al. (2014) & Zambia & $5.1-6.9$ & $3.5-15$ & $1.7-15$ & VS & $x$ & Enchytraeus crypticus & - & - & 351 \\
\hline Naveed et al. (2014) & Denmark & $5.9-6.6$ & NA & $3.3-6.0$ & VS & $\sqrt{ }$ & Native earthworms & 110 & - & - \\
\hline Delgadillo et al. (2017) & Chile & $5.7-8.3$ & NA & $0.7-10$ & VS & $\sqrt{ }$ & Eisenia fetida & - & - & 213 \\
\hline Mirmonsef et al. (2017) & Denmark & NA & NA & NA & VS & $\sqrt{ }$ & Aporrectodea tuberculata & - & - & 220 \\
\hline & & & & & & & Worm mean & 123 & - & 282 \\
\hline \multicolumn{11}{|c|}{ Microorganisms } \\
\hline Baath et al. (1991) & Sweden & NA & NA & NA & VS & $x$ & Native microbes & - & - & $2500^{c}$ \\
\hline Sauvé (2006) & Denmark & $6.0-7.1$ & NA & $3.7-5.1$ & VS & $\sqrt{ }$ & Native microbes & 154 & $193^{b}$ & 285 \\
\hline Arthur et al. (2012) & Denmark & $6.1-6.6$ & NA & $2.7-5.1$ & VS & $\sqrt{ }$ & Native microbes & - & - & 532 \\
\hline Naveed et al. (2014) & Denmark & $5.9-6.6$ & NA & $3.3-6.0$ & VS & $\sqrt{ }$ & Native microbes & 575 & - & - \\
\hline & & & & & & & Microbe mean & 365 & - & 408 \\
\hline
\end{tabular}




\begin{tabular}{|c|c|c|c|c|c|c|c|c|c|c|}
\hline \multicolumn{11}{|c|}{ a. Archaea/Bacteria } \\
\hline Mertens et al. (2010) & Denmark & $5.2-5.9$ & 6.7 & 3.6 & VS & $\sqrt{ }$ & $\mathrm{AOA}$ and $\mathrm{AOB}$ & - & - & $2060^{c}$ \\
\hline Naveed et al. (2014) & Denmark & $5.9-6.6$ & NA & $3.3-6.0$ & VS & $\sqrt{ }$ & Native bacteria & 170 & - & - \\
\hline \multicolumn{11}{|c|}{ b. Fungi } \\
\hline Naveed et al. (2014) & Denmark & $5.9-6.6$ & NA & $3.3-6.0$ & VS & $\sqrt{ }$ & Native fungi & 1585 & - & - \\
\hline \multicolumn{11}{|c|}{ Soil properties } \\
\hline Naveed et al. (2014) & Denmark & $5.9-6.6$ & NA & $3.3-6.0$ & VS & $\sqrt{ }$ & $\begin{array}{c}\text { Physical and chemical } \\
\text { properties }\end{array}$ & 311 & - & - \\
\hline
\end{tabular}

AOA and AOB: ammonia-oxidizing archaea and ammonia-oxidizing bacteria community; CEC: cation exchange capacity; $D$ : the study demonstrates the impact of a single pollutant on biological responses?; " $x$ " means "no", whereas " $\sqrt{ }$ " means "yes"; F: fading with uncontaminated soil or with artificial OECD soil (sphagnum peat 10\% w/w, kaolinite clay 20\% w/w, quartz sand 70\% w/w); M: method; VS: various field-collected soils; native microbes: biological response is attributed to several soil microorganism taxa (i.e., archaea, bacteria, actinomycete, algae, fungi, and protozoa); NA: not available; OM: organic matter; SO: soil origin. ${ }^{a}$ Mean value for several soils. ${ }^{b} E_{20}$ instead of $E_{25}$ (not included in the mean). ${ }^{c}$ Not included in the mean.

Appendix $\mathrm{H}$. Effective concentrations $\left(E C_{x}\right)$ of extractable and soluble copper pools, and free copper ion

\begin{tabular}{|c|c|c|c|c|c|c|c|c|c|}
\hline \multirow{2}{*}{ Study } & \multirow{2}{*}{ Species } & \multirow{2}{*}{ Extractant } & \multirow{2}{*}{$\frac{\mathrm{Cu}_{\text {extractable }}\left(\mathrm{mg} \mathrm{kg}^{-1}\right)}{\mathrm{EC}_{50}}$} & \multicolumn{3}{|c|}{$\mathrm{Cu}_{\text {soluble }}\left(\mu \mathrm{g} \mathrm{L}^{-1}\right)$} & \multicolumn{3}{|c|}{$\mathrm{pCu}^{2+}$} \\
\hline & & & & $\mathrm{EC}_{10}$ & $\mathrm{EC}_{25}$ & $\mathrm{EC}_{50}$ & $\mathrm{EC}_{10}$ & $\mathrm{EC}_{25}$ & $\mathrm{EC}_{50}$ \\
\hline \multicolumn{10}{|c|}{ Plants } \\
\hline \multirow{5}{*}{$\begin{array}{l}\text { Hamels et al. } \\
\text { (2014) }\end{array}$} & \multirow{5}{*}{$\begin{array}{l}\text { Hordeum vulgare } \\
\text { (Barley) }\end{array}$} & 0.0155 M Cohex, SSR: NA & 50 & - & - & - & - & - & - \\
\hline & & $1 \mathrm{M} \mathrm{NH}_{4} \mathrm{NO}_{3}, \mathrm{SSR}: 1 / 2.5$ & 8.9 & - & - & - & - & - & - \\
\hline & & 0.05 M EDTA, SSR: 1/2.5 & 930 & - & - & - & - & - & - \\
\hline & & $0.001 \mathrm{M} \mathrm{CaCl}_{2^{\prime}}$ SSR: $1 / 10$ & - & - & - & 390 & - & - & - \\
\hline & & $C_{D G T}$ & - & - & - & 40 & - & - & - \\
\hline $\begin{array}{l}\text { Kolbas et al. } \\
\text { (2014) }\end{array}$ & $\begin{array}{l}\text { Helianthus annuus } \\
\text { (Sunflower) }\end{array}$ & Pore water & - & 311 & - & 580 & 7.1 & - & 6.3 \\
\hline $\begin{array}{l}\text { Kolbas et al. } \\
\text { (2018) }\end{array}$ & $\begin{array}{l}\text { Helianthus annuus } \\
\text { (Sunflower) }\end{array}$ & Pore water & - & - & - & 361 & - & - & - \\
\hline \multirow[t]{2}{*}{$\begin{array}{l}\text { Lillo-Robles et al. } \\
\qquad(2020)\end{array}$} & Several species & $0.1 \mathrm{M} \mathrm{KNO}_{3^{\prime}} \mathrm{SSR}: 1 / 2.5$ & - & 267 & 397 & 539 & 7.5 & 6.8 & 5.9 \\
\hline & Plant mean & Pore water & - & - & - & 471 & - & - & - \\
\hline \multicolumn{10}{|c|}{ Worms } \\
\hline $\begin{array}{l}\text { Konečný et al. } \\
\text { (2014) }\end{array}$ & $\begin{array}{l}\text { Enchytraeus } \\
\text { crypticus }\end{array}$ & $\begin{array}{c}0.05 \text { M EDTA, SSR: 1/2.5 } \\
\text { (recalculated from } \\
\text { SSR: 1/10) }\end{array}$ & 398 & - & - & - & - & - & - \\
\hline \multicolumn{10}{|c|}{ Microorganisms } \\
\hline $\begin{array}{c}\text { Aponte et al. } \\
\text { (2021) }\end{array}$ & Native microbes & NA M DTPA, SSR: NA & 139 & - & - & - & - & - & - \\
\hline
\end{tabular}

$C_{D G T}$ : Diffusive gradients in thin films measured concentration; NA: not available; SSR: soil/solution ratio.

Lillo-Robles et al. (2020): various Chilean field-collected soils with $\mathrm{pH}$ 4.9-7.1 and 0.9-8.0\% organic matter. This study demonstrates the impact of a single pollutant on biological responses.

Aponte et al. (2021): various Chilean field-collected soils with pH 4.7-5.9 and 1.0-2.8\% organic matter. This study demonstrates the impact of a single pollutant on biological responses. 
Appendix I. Total effective concentrations $\left(E C_{x}\right)$ of nickel and the properties of soils under study

\begin{tabular}{|c|c|c|c|c|c|c|c|c|c|}
\hline \multirow{2}{*}{ Study } & \multirow{2}{*}{ SO } & \multicolumn{3}{|c|}{ Soil properties } & \multirow{2}{*}{ M } & \multirow{2}{*}{$\mathrm{D}$} & \multirow{2}{*}{ Species } & \multicolumn{2}{|c|}{$\mathrm{Ni}_{\text {total }}\left(\mathrm{mg} \mathrm{kg}^{-1}\right)$} \\
\hline & & $\mathrm{pH}$ & $\mathrm{CEC}\left(\mathrm{cmol}_{+} \mathrm{kg}^{-1}\right)$ & $\mathrm{OM}(\%)$ & & & & $\mathrm{EC}_{25}$ & $\mathrm{EC}_{50}$ \\
\hline \multicolumn{10}{|c|}{ Plants } \\
\hline Dan et al. (2008) & Canada & $5.7-6.9$ & $5.0-63$ & $6.0-28$ & VS & $\sqrt{ }$ & Avena sativa (Oat) & $1727^{a}$ & - \\
\hline \multirow{2}{*}{ Cioccio et al. (2017) } & \multirow{2}{*}{ Canada } & $4.6-6.1$ & $23-54$ & $9.6-25$ & VS & $\sqrt{ }$ & Avena sativa (Oat) & - & 1270 \\
\hline & & NA & NA & NA & VS & $\sqrt{ }$ & Glycine max (Soybean) & - & 1590 \\
\hline Gopalapillai et al. (2019) & Canada & $5.5-7.4$ & $9.7-49$ & $3.6-18$ & $\mathrm{~F}$ & $\sqrt{ }$ & Avena sativa (Oat) & - & $2269^{a}$ \\
\hline & & & & & & & Plant mean & 1727 & 1710 \\
\hline
\end{tabular}

CEC: cation exchange capacity; D: the study demonstrates the impact of a single pollutant on biological responses?; " $x$ " means "no", whereas " V" means "yes"; F: fading with uncontaminated soil; M: method; VS: various field-collected soils; NA: not available; OM: organic matter; SO: soil origin. ${ }^{a}$ Mean value for several soils.

Appendix J. Effective concentrations $\left(\mathrm{EC}_{\mathrm{x}}\right.$ ) of extractable and soluble nickel pools, and free nickel ion

\begin{tabular}{|c|c|c|c|c|c|c|}
\hline \multirow[t]{2}{*}{ Study } & \multirow[t]{2}{*}{ Species } & \multirow{2}{*}{ Extractant } & \multicolumn{2}{|c|}{$\mathrm{Ni}_{\text {extractable }}\left(\mathrm{mg} \mathrm{kg}^{-1}\right)$} & \multirow{2}{*}{$\begin{array}{c}\begin{array}{c}\mathrm{Ni}_{\text {soluble }} \\
\left(\mu \mathrm{L}^{-1}\right)\end{array} \\
\mathrm{EC}_{25}\end{array}$} & \multirow{2}{*}{$\begin{array}{c}\mathrm{pNi}^{2+} \\
\mathrm{EC}_{50}\end{array}$} \\
\hline & & & $\mathrm{EC}_{25}$ & $\mathrm{EC}_{50}$ & & \\
\hline \multicolumn{7}{|c|}{ Plants } \\
\hline Kukier and Chaney (2004) & Several species & $0.01 \mathrm{M} \mathrm{Sr}\left(\mathrm{NO}_{3}\right)_{2^{\prime}} \mathrm{SSR}: 1 / 4$ & - & - & 9.3 & - \\
\hline Dan et al. (2008) & Avena sativa (Oat) & $0.2 \mathrm{M} \mathrm{C}_{2} \mathrm{H}_{2} \mathrm{O}_{4}+\left(\mathrm{NH}_{4}\right)_{2} \mathrm{C}_{2} \mathrm{O}_{4^{\prime}}$ SSR: $1 / 20$ & $465^{\mathrm{a}}$ & - & - & - \\
\hline \multirow{2}{*}{ Gopalapillai et al. (2019) } & \multirow{2}{*}{ Avena sativa (Oat) } & $0.2 \mathrm{M} \mathrm{C}_{2} \mathrm{H}_{2} \mathrm{O}_{4}+\left(\mathrm{NH}_{4}\right)_{2} \mathrm{C}_{2} \mathrm{O}_{4^{\prime}}$ SSR: $1 / 20$ & - & $607^{\mathrm{a}}$ & - & - \\
\hline & & Pore water & - & - & - & $6.8^{\mathrm{a}}$ \\
\hline
\end{tabular}

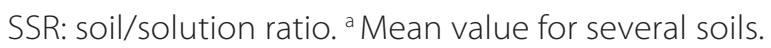

Kukier and Chaney (2004): Canadian field-collected soil artificially adjusted to pH 5.2-7.8 by adding $\mathrm{CaCO}_{3}$ and $\mathrm{MgCO}_{3}$; contains $17 \%$ of organic matter. The study demonstrates the impact of a single pollutant on biological responses.

Appendix K. Total effective concentrations $\left(E C_{x}\right)$ of lead and the properties of soils under study

\begin{tabular}{|c|c|c|c|c|c|c|c|c|c|}
\hline \multirow{2}{*}{ Study } & \multirow{2}{*}{ SO } & \multicolumn{3}{|c|}{ Soil properties } & \multirow{2}{*}{$M$} & \multirow{2}{*}{ D } & \multirow{2}{*}{ Species } & \multicolumn{2}{|c|}{$\mathrm{Pb}_{\text {total }}\left(\mathrm{mg} \mathrm{kg}^{-1}\right)$} \\
\hline & & $\mathrm{pH}$ & $\mathrm{CEC}\left(\mathrm{cmol}_{+} \mathrm{kg}^{-1}\right)$ & OM (\%) & & & & $\mathrm{EC}_{10}$ & $\mathrm{EC}_{50}$ \\
\hline \multicolumn{10}{|c|}{ Invertebrates } \\
\hline \multicolumn{10}{|c|}{ a. Mites } \\
\hline Luo et al. (2015) & Netherlands & $3.2-6.8$ & $1.8-21$ & $3.8-13$ & VS & $\sqrt{ }$ & Platynothrus peltifer & 658 & 696 \\
\hline \multicolumn{10}{|c|}{ b. Worms } \\
\hline Hui et al. (2009) & Finland & NA & NA & NA & $\mathrm{F}$ & $x$ & Native enchytraeids & - & $11,030^{\mathrm{a}}$ \\
\hline Luo et al. (2014b) & Netherlands & $3.2-6.8$ & $1.8-21$ & 3.8-13 & VS & $\sqrt{ }$ & Eisenia andrei & 1377 & 1543 \\
\hline Luo et al. (2014a) & Netherlands & $3.2-6.8$ & $1.8-21$ & $3.8-13$ & VS & $\sqrt{ }$ & Enchytraeus crypticus & 583 & 642 \\
\hline & & & & & & & Worm mean & 980 & 1092 \\
\hline \multicolumn{10}{|c|}{ Microorganisms } \\
\hline $\begin{array}{c}\text { Vanhala and Ahtiainen } \\
\text { (1994) }\end{array}$ & Finland & $3.1-4.8$ & NA & NA & VS & $x$ & Native microbes & - & 46,850 \\
\hline
\end{tabular}

CEC: cation exchange capacity; $D$ : the study demonstrates the impact of a single pollutant on biological responses?; " $x$ " means "no", whereas "ل" means "yes"; F: fading with uncontaminated soil; M: method; Vs: various field-collected soils; native microbes: biological response is attributed to several soil microorganism taxa (i.e., archaea, bacteria, actinomycete, algae,

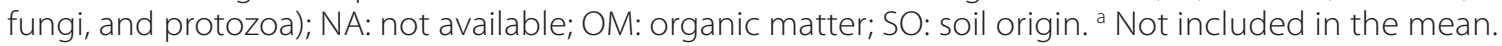


Appendix L. Effective concentrations $\left(E C_{x}\right)$ of extractable and soluble lead pools

\begin{tabular}{|c|c|c|c|c|c|c|}
\hline \multirow{2}{*}{ Study } & \multirow{2}{*}{ Species } & \multirow{2}{*}{ Extractant } & \multicolumn{2}{|c|}{$\mathrm{Pb}_{\text {extractable }}\left(\mathrm{mg} \mathrm{kg}^{-1}\right)$} & \multicolumn{2}{|c|}{$\mathrm{Pb}_{\text {soluble }}\left(\mu \mathrm{g} \mathrm{L}^{-1}\right)$} \\
\hline & & & $\mathrm{EC}_{10}$ & $\mathrm{EC}_{50}$ & $\mathrm{EC}_{10}$ & $\mathrm{EC}_{50}$ \\
\hline \multicolumn{7}{|c|}{ Invertebrates } \\
\hline \multicolumn{7}{|c|}{ a. Mites } \\
\hline \multirow{3}{*}{ Luo et al. (2015) } & \multirow{3}{*}{ Platynothrus peltifer } & Water, SSR: 1/5 & 2.2 & 5.5 & - & - \\
\hline & & $0.01 \mathrm{M} \mathrm{CaCl}_{2^{\prime}}$ SSR: $1 / 5$ & 7.2 & 49 & - & - \\
\hline & & Pore water & - & - & 3040 & 6418 \\
\hline \multicolumn{7}{|c|}{ b. Worms } \\
\hline \multirow{3}{*}{ Luo et al. (2014b) } & \multirow{3}{*}{ Eisenia andrei } & Water, SSR: $1 / 5$ & 0.4 & 3.0 & - & - \\
\hline & & $0.01 \mathrm{M} \mathrm{CaCl}_{2^{\prime}}$ SSR: $1 / 5$ & 0.4 & 50 & - & - \\
\hline & & Pore water & - & - & 99,000 & 67,550 \\
\hline \multirow{6}{*}{ Luo et al. (2014a) } & \multirow{3}{*}{ Enchytraeus crypticus } & Water, SSR: 1/5 & 0.4 & 1.0 & - & - \\
\hline & & $0.01 \mathrm{M} \mathrm{CaCl}_{2^{\prime}}$ SSR: $1 / 5$ & 1.3 & 5.1 & - & - \\
\hline & & Pore water & - & - & 119 & 385 \\
\hline & \multirow{3}{*}{ Worm mean } & Water, SSR: 1/5 & 0.4 & 2.0 & - & - \\
\hline & & $0.01 \mathrm{M} \mathrm{CaCl}_{2}$, SSR: $1 / 5$ & 0.9 & 28 & - & - \\
\hline & & Pore water & - & - & 49,560 & 33,967 \\
\hline
\end{tabular}

SSR: soil/solution ratio.

Appendix $M$. Total effective concentrations $\left(E C_{x}\right)$ of zinc and the properties of soils under study

\begin{tabular}{|c|c|c|c|c|c|c|c|c|c|}
\hline \multirow{2}{*}{ Study } & \multirow{2}{*}{ SO } & \multicolumn{3}{|c|}{ Soil properties } & \multirow{2}{*}{ M } & \multirow{2}{*}{$\mathrm{D}$} & \multirow{2}{*}{ Species } & \multicolumn{2}{|c|}{$\mathrm{Zn}_{\text {total }}\left(\mathrm{mg} \mathrm{kg}^{-1}\right)$} \\
\hline & & $\mathrm{pH}$ & $\mathrm{CEC}\left(\mathrm{cmol}_{+} \mathrm{kg}^{-1}\right)$ & OM (\%) & & & & $\mathrm{EC}_{10}$ & $\mathrm{EC}_{50}$ \\
\hline \multicolumn{10}{|c|}{ Plants } \\
\hline De Knecht et al. (1998) & Netherlands & NA & NA & NA & VS & $x$ & $\begin{array}{l}\text { Trifolium pratense } \\
\text { (Red clover) }\end{array}$ & - & 347 \\
\hline Smolders et al. (2002) & Belgium & $5.5-6.1$ & $17-21$ & $6.0-13$ & VS & $x$ & $\begin{array}{l}\text { Triticum aestivum } \\
\text { (Wheat) }\end{array}$ & 217 & 1215 \\
\hline Beyer et al. (2011) & United States & $3.8-4.8$ & NA & NA & VS & $x$ & Several species & - & 2359 \\
\hline Beyer et al. (2013) & United States & $3.6-4.2$ & $14-16$ & $8.0-13$ & $\mathrm{~F}$ & $x$ & Several species & - & 311 \\
\hline Hamels et al. (2014) & Belgium / France & $4.8-7.6$ & $1.0-69$ & $1.7-40$ & $\mathrm{~F}$ & $\sqrt{ }$ & $\begin{array}{l}\text { Hordeum vulgare } \\
\text { (Barley) }\end{array}$ & - & $9820^{a}$ \\
\hline & & & & & & & Plant mean & 217 & 1561 \\
\hline \multicolumn{10}{|c|}{ Invertebrates } \\
\hline Spurgeon et al. (2005) & United Kingdom & $3.7-7.1$ & NA & NA & VS & $x$ & $\begin{array}{l}\text { Decomposer } \\
\text { community }\end{array}$ & - & 979 \\
\hline \multicolumn{10}{|c|}{ a. Springtails } \\
\hline $\begin{array}{l}\text { Mertens and Smolders } \\
\text { (2013) }\end{array}$ & $\begin{array}{l}\text { Belgium / United } \\
\text { Kingdom }\end{array}$ & NA & NA & NA & VS & $x$ & Folsomia candida & 507 & - \\
\hline \multicolumn{10}{|c|}{ b. Worms } \\
\hline $\begin{array}{c}\text { Spurgeon and Hopkin } \\
\text { (1995) }\end{array}$ & United Kingdom & $5.5-7.4$ & NA & $9.4-27$ & VS & $x$ & Eisenia fetida & - & 3605 \\
\hline $\begin{array}{c}\text { Posthuma and } \\
\text { Notenboom (1996) }\end{array}$ & Netherlands & 5.5 & NA & $1.9-6.4$ & VS & $x$ & Several species & - & 1379 \\
\hline
\end{tabular}




\begin{tabular}{|c|c|c|c|c|c|c|c|c|c|}
\hline $\begin{array}{c}\text { Spurgeon and Hopkin } \\
\text { (1996) }\end{array}$ & United Kingdom & $5.5-7.4$ & NA & $9.4-27$ & VS & $x$ & Eisenia fetida & - & 1872 \\
\hline $\begin{array}{c}\text { Nahmani and Lavelle } \\
\text { (2002) }\end{array}$ & France & NA & NA & NA & VS & $x$ & $\begin{array}{c}\text { Aporrectodea } \\
\text { caliginosa }\end{array}$ & - & $2000^{b}$ \\
\hline \multirow{2}{*}{ Spurgeon et al. (2005) } & \multirow{2}{*}{ United Kingdom } & NA & NA & NA & VS & $x$ & Lumbricus rubellus & - & 1499 \\
\hline & & $5.4-7.4$ & NA & NA & VS & $x$ & Native earthworms & - & 1737 \\
\hline $\begin{array}{c}\text { Mertens and Smolders } \\
\text { (2013) }\end{array}$ & $\begin{array}{l}\text { Belgium / United } \\
\text { Kingdom }\end{array}$ & NA & NA & NA & VS & $x$ & Eisenia fetida & $924^{a}$ & - \\
\hline & & & & & & & Worm mean & 924 & 1912 \\
\hline \multicolumn{10}{|c|}{ Microorganisms } \\
\hline $\begin{array}{c}\text { Vanhala and Ahtiainen } \\
\text { (1994) }\end{array}$ & Finland & $4.3-7.2$ & NA & NA & VS & $x$ & Native microbes & - & 2775 \\
\hline \multicolumn{10}{|c|}{ a. Bacteria } \\
\hline $\begin{array}{l}\text { Broos et al. (2005), } \\
\text { Broos et al. (2004) }\end{array}$ & United Kingdom & $5.2-5.7$ & $2.5-4.7$ & NA & VS & $x$ & $\begin{array}{c}\text { Rhizobium } \\
\text { leguminosarum }\end{array}$ & - & 403 \\
\hline
\end{tabular}

CEC: cation exchange capacity; decomposer community: biological response is attributed to several soil organism taxa (i.e., earthworms, isopods, microbes, mites, mollusks, myriapods and springtails); D: the study demonstrates the impact of a single pollutant on biological responses?; "X" means "no", whereas " $\sqrt{ }$ " means "yes"; F: fading with uncontaminated soil; M: method; VS: various field-collected soils; native microbes: biological response is attributed to several soil microorganism taxa (i.e., archaea, bacteria, actinomycete, algae, fungi, and protozoa); NA: not available; OM: organic matter; SO: soil origin.

${ }^{a}$ Mean value for several soils. ${ }^{b} \mathrm{EC}_{100}$ instead of $\mathrm{EC}_{50}$ (not included in the mean).

\section{Appendix N. Extractable, soluble, and free zinc ion effective concentrations $\left(\mathrm{EC}_{\mathrm{x}}\right)$}

\begin{tabular}{|c|c|c|c|c|c|c|c|}
\hline \multirow{2}{*}{ Study } & \multirow{2}{*}{ Species } & \multirow{2}{*}{ Extractant } & \multirow{2}{*}{$\frac{\mathrm{Zn} \mathrm{n}_{\text {extractable }}\left(\mathrm{mg} \mathrm{kg}^{-1}\right)}{\mathrm{EC}_{50}}$} & \multicolumn{2}{|c|}{$Z n_{\text {soluble }}\left(\mu \mathrm{g} \mathrm{L}^{-1}\right)$} & \multicolumn{2}{|c|}{$\mathrm{pZn}^{2+}$} \\
\hline & & & & $\mathrm{EC}_{10}$ & $\mathrm{EC}_{50}$ & $\mathrm{EC}_{10}$ & $\mathrm{EC}_{50}$ \\
\hline \multicolumn{8}{|c|}{ Plants } \\
\hline De Knecht et al. (1998) & $\begin{array}{l}\text { Trifolium pratense } \\
\text { (Red clover) }\end{array}$ & $0.01 \mathrm{CaCl}_{2^{\prime}}$ SSR: NA & 121 & - & - & - & - \\
\hline \multirow{2}{*}{ Smolders et al. (2002) } & \multirow{2}{*}{$\begin{array}{l}\text { Triticum aestivum } \\
\text { (Wheat) }\end{array}$} & Pore water & - & 400 & 6900 & - & - \\
\hline & & $C_{D G T}$ & - & 150 & 4410 & - & - \\
\hline Nolan et al. (2005) & $\begin{array}{l}\text { Triticum aestivum } \\
\text { (Wheat) }\end{array}$ & Pore water & - & - & - & 3.9 & 3.4 \\
\hline Beyer et al. (2011) & Several species & $0.01 \mathrm{M} \mathrm{Sr}\left(\mathrm{NO}_{3}\right)_{2^{\prime}}$ SSR: $1 / 4$ & 120 & - & - & - & - \\
\hline \multirow{2}{*}{ Beyer et al. (2013) } & \multirow{2}{*}{ Several species } & $0.01 \mathrm{M} \mathrm{Sr}\left(\mathrm{NO}_{3}\right)_{2^{\prime}}, \mathrm{SSR}: 1 / 4$ & 52 & - & - & - & - \\
\hline & & Mehlich 3, SSR: NA & 95 & - & - & - & - \\
\hline \multirow{7}{*}{ Hamels et al. (2014) } & \multirow{5}{*}{$\begin{array}{l}\text { Hordeum vulgare } \\
\text { (Barley) }\end{array}$} & 0.0155 M Cohex, SSR: NA & $327^{\mathrm{a}}$ & - & - & - & - \\
\hline & & $1 \mathrm{M} \mathrm{NH}_{4} \mathrm{NO}_{3^{\prime}} \mathrm{SSR}: 1 / 2.5$ & $145 a$ & - & - & - & - \\
\hline & & 0.05 M EDTA, SSR: $1 / 2.5$ & $3798^{a}$ & - & - & - & - \\
\hline & & $0.001 \mathrm{M} \mathrm{CaCl}_{2^{\prime}}$ SSR: $1 / 10$ & - & - & $2388^{a}$ & - & - \\
\hline & & $C_{D G T}$ & - & - & $2770^{a}$ & - & - \\
\hline & \multirow{2}{*}{ Plant mean } & $0.01 \mathrm{M} \mathrm{Sr}\left(\mathrm{NO}_{3}\right)_{2}, \mathrm{SSR}: 1 / 4$ & 62 & - & - & - & - \\
\hline & & $C_{D G T}$ & - & - & 3590 & - & - \\
\hline \multicolumn{8}{|c|}{ Invertebrates: Worms } \\
\hline $\begin{array}{l}\text { Spurgeon and Hopkin } \\
\text { (1995) }\end{array}$ & Eisenia fetida & Water, SSR: $1 / 13$ to $1 / 17$ & 21 & - & - & - & - \\
\hline \multirow{2}{*}{$\begin{array}{c}\text { Posthuma and } \\
\text { Notenboom (1996) }\end{array}$} & \multirow{2}{*}{ Several species } & $0.01 \mathrm{M} \mathrm{CaCl}_{2^{\prime}}$ SSR: $1 / 10$ & 95 & - & - & - & - \\
\hline & & Pore water & - & - & 21,135 & - & - \\
\hline
\end{tabular}




\begin{tabular}{|c|c|c|c|c|c|c|c|}
\hline \multicolumn{8}{|c|}{ Microorganisms } \\
\hline \multirow{2}{*}{ Lessard et al. (2014b) } & \multirow{2}{*}{ Native microbes } & $0.01 \mathrm{M} \mathrm{KNO}_{3^{\prime}}$ SSR: $1 / 2$ & - & - & 8031 & - & - \\
\hline & & ASV: $0.01 \mathrm{M} \mathrm{KNO}_{3^{\prime}}$ SSR: $1 / 2$ & - & - & 9481 & - & - \\
\hline \multirow[t]{2}{*}{ Lessard et al. (2014a) } & Native microbes & ASV: $0.01 \mathrm{M} \mathrm{KNO}_{3^{\prime}}$ SSR: $1 / 2$ & - & - & 400 & - & - \\
\hline & Microbe mean & ASV: $0.01 \mathrm{M} \mathrm{KNO}_{3^{\prime}}$ SSR: $1 / 2$ & - & - & 4940 & - & - \\
\hline
\end{tabular}

ASV: measured by square wave anodic stripping voltammetry; $C_{D G T}$ : diffusive gradients in thin films measured concentration; EP: endpoint; native microbes: biological response is attributed to several soil microorganism taxa (i.e., archaea, bacteria, actinomycete, algae, fungi, and protozoa); NA: not available; TD: test duration (days); SSR: soil/solution ratio. ${ }^{a}$ Mean value for several soils.

Lessard et al. (2014a): various Canadian field-collected soils. The study demonstrates the impact of a single pollutant on biological responses.

Lessard et al. (2014b): various Canadian various field-collected soils with pH 3.3-7.1, CEC 15-247 cmol $\mathrm{kg}^{-1}$, and 1.6-70.3\% organic matter. The study demonstrates the impact of a single pollutant on biological responses.

Nolan et al. (2005): various Australian and United States field-collected soils, with pH 3.6-8.1 and 0.2-20\% of organic matter. The study, however, does not demonstrate the impact of a single pollutant on biological responses. 